Czekalowski, J. W., McLeod, J. W. \& Rodican, J. (1954). J. gen. Microbiol., 10, 199-208.

\title{
Observations on the Nutrition of Leptospira based on the Development of Dinger's Phenomenon
}

\author{
By J. W. CZEKALOWSKI, J. W. MCLEOD \\ AND J. RODICAN \\ Department of Bacteriology, Leeds University
}

\begin{abstract}
SUMMARY: The speed of development of narrow zones of opacity due to massed growth of leptospira a few millimetres below the surface in cultures in soft agar, a phenomenon first fully described by Dinger (1932), has been used as a criterion of the nutritional value of media for certain pathogenic leptospira. In applying this test to assess the value of the addition of peptone to a basal medium of $10 \%(\mathrm{v} / \mathrm{v})$ rabbit serum in diluted meat extract, the impression was formed that peptones contained substances which promoted growth and others which were inhibitory. Witte's peptone was the most constantly favourable of those which were tested. Tryptic digest broth (Hartley's) gave results at least as good. Inhibitory effects with peptone may develop on autoclaving, especially at high $\mathrm{pH}$ values, or on leaving sterilized solutions to stand for considerable periods at room temperature. The value of haemoglobin (as laked blood) may depend on its catalase content since Czekalowski, McLeod \& Rodican (1953) showed that leptospira did not produce this enzyme. The range of $\mathrm{pH}$ suitable for the development of cultures is narrow with $\mathrm{pH} \mathrm{7.6}$ as optimum; but the leptospira are more tolerant to divergences on the alkaline side in the media at the time of inoculation.
\end{abstract}

Dinger (1932) described the development in cultures of leptospira, in deep tubes of soft agar, of dense narrow rings of growth a few millimetres below the surface which were very sharply demareated on the under side but less so above. These resembled opaque disks inserted in a cylinder of medium which was otherwise relatively transparent; although a photograph of something very similar had been published by Fletcher earlier (1928) the phenomenon has till quite recently received little attention. It was investigated afresh by Lawrence (1951) and by Czekalowski, McLeod \& Rodican (1953). Since this appearance is very characteristic, is only observed when the leptospira are growing well and can be accepted as evidence that the culture is in fact one of leptospira, we considered that it might be used as a criterion of the value of various media for the growth of these micro-organisms.

The outstanding early work on the culture of leptospira was that of Noguchi (1918); but in recent years the media mainly used have been (a) Korthof's (1928) medium which is stated by Wiesmann (1952) to be the most widely adopted at the present time, $(b)$ Vervoort's (1923) medium or modifications of it, and $(c)$ Fletcher's (1928) medium. The basis of the first two is a dilute solution of Witte's peptone $(c .0 .1 \%)$, but whereas Korthof dissolved the peptone in a balanced solution of salts to obtain a $\mathrm{pH}$ of $\mathbf{7 \cdot 2 - 7 \cdot 4}$ Vervoort used dilute phosphoric acid in order to obtain a $\mathrm{pH}$ of $6 \cdot 6$ which was corrected to 7.1 on addition of $10 \%(\mathrm{v} / \mathrm{v})$ of serum. Fletcher's medium differs in that the salt balance and phosphate content depend on the dilution of nutrient 
agar; the peptone used was not specified. In Britain, amongst those who have worked most with leptospira in recent years, Broom (personal communication) has used a modified Korthof medium consisting of $7 \%$ (v/v) of serum in Locke's solution with a little added haemoglobin; Davidson, Campbell, Rae \& Smith (1934) used a medium which they described as that of the Dutch workers. Stuart (1946), who has made a very thorough study of the nutrition of leptospira, introduced a new medium which he has compared with those of Korthof and Schüffner.

One respect in which all media recommended for the growth of leptospira are alike is that their content of commonly used organic nitrogenous constituents is low. The only account of detailed experimental work on which this practice is based is that of Noguchi (1918). He stated that the organisms cannot be grown in any of the usual bacteriological media and that in serum + Ringer solution media, which are otherwise suitable, even $1.5 \%$ of peptone will cause marked suppression of growth. The modern media used by continental workers contain only $0.1 \%$ peptone and it is stressed that this should be Witte's. Broom uses neither peptone nor meat extract; Stuart $(1943,1946)$ recommended low concentrations of asparagine and $\mathrm{NH}_{4} \mathrm{Cl}$ as sources of nitrogen. Stuart found his medium superior to those of the Dutch in ability to yield abundant growths of the largest proportion of all strains of leptospira tested, although he admitted that the Dutch media had the advantage of being suitable with a wider range of rabbit sera.

There is a consensus of opinion that serum is essential, and that of those readily available rabbit is best at a concentration of about $10 \%(\mathrm{v} / \mathrm{v})$. Some rabbit sera are inhibitory, however, and Stuart (1943) found fifteen such out of 104 tested. They did not fail owing to deficiency, and the inhibitory effect was not due to adverse $\mathrm{pH}$ values nor to the presence of antibodies; the inhibition disappeared on heating to $80^{\circ}$ and was partly removed by ether extraction. Opinion is divided about the value of haemoglobin; whereas it is recommended by some experienced workers as a useful addition to media, Wiesmann (1952), using Korthof's medium prepared with fresh rabbit serum (obtained under aseptic conditions and not filtered), did not observe any advantage from adding it. Another aspect in which there is diversity of practice in preparing media for leptospira is in the $\mathrm{pH}$ value of the basal medium in which serum is incorporated.

In the Dutch papers $\mathrm{pH}$ values ranging from $6 \cdot 6$ to $7 \cdot 4$ are recommended (Vervoort, 1923; Korthof, 1928; Dinger, 1932; Walch-Sorgdrager, Schüffner \& Bohlander, 1938; van Thiel, 1948). Walch-Sorgdrager et al. (1938) met Zuelzer's (1936) criticism that agglutination results may be adversely affected in slightly acid media with the statement that basal media of $\mathrm{pH} 7 \cdot 1$ as used by them are invariably brought to $\mathrm{pH} \mathbf{7 . 5}$ by the addition of the fresh rabbit serum; this they consider to be an optimal $\mathrm{pH}$ value. Stuart (1943), however, pointed out that rabbit sera of $\mathrm{pH} 7 \cdot 0$ may be met occasionally and that samples of medium complete with serum may with time fall below $\mathrm{pH} \mathbf{7 \cdot 0}$. For this reason he recommended the addition of a trace of phenol red as indicator and used buffer at $\mathrm{pH} 7 \cdot 6$ in making up his basal medium. 
It seemed to us that in view of these varying recommendations it would be useful to check the value of certain ingredients and properties of media used in cultivating leptospira, taking speed of development of the Dinger disk as an easily observed and reliable criterion of a good medium. Our investigations were chiefly related to the value of various protein digest products and to the influence of the $\mathrm{pH}$ value of the medium on the initiation and persistence of growth.

\section{EXPERIMENTAL}

Organisms. The strain Wijnberg of Leptospira icterohaemorrhagiae and strain Aldgate of $L$. canicola were used throughout.

\section{Effect of different solutions and methods of preparation on leptospiral growth}

Comparison of Witte and Oxo peptones. In view of the complete failure of all media made up with one batch of Oxo peptone and the uniformly successful results obtained with another we began by comparing a third batch (which was not inhibitory in the way that the second had been) with an old sample of Witte peptone from laboratory stock, since it appears to be generally accepted that Witte peptone is that most suited to the growth of leptospira. In all these experiments the basal medium was extract of fresh meat (beef) $500 \mathrm{~g} . / 1000 \mathrm{ml}$. diluted $1 / 8$ or $1 / 10$ with water and sterilized by filtration through a Maassen or Chamberland candle after addition of $10 \%(\mathrm{v} / \mathrm{v})$ of rabbit or other suitable serum. This medium was heated for $30 \mathrm{~min}$. or more at $56^{\circ}$ and, after addition of the substance under investigation, three parts of the fluid medium so obtained were added to one part of $4 \%(\mathrm{w} / \mathrm{v})$ agar so as to give a final agar concentration of $1 \%$. The completed medium $(6.0 \mathrm{ml}$.) was held for $10 \mathrm{~min}$. or more at $39^{\circ}$ in a water bath, inoculated with $0.25 \mathrm{ml}$. of a liquid culture of leptospira, thoroughly mixed with a large pipette and allowed to set. It was incubated at $30^{\circ}$. The peptone solutions used in the first experiment were made up at $4 \%(\mathrm{w} / \mathrm{v})$, brought to $\mathrm{pH} 7 \cdot 8$ and sterilized in the autoclave at $10 \mathrm{lb} . / \mathrm{sq}$.in. for $20 \mathrm{~min}$. The results obtained with varying concentrations of the two peptone solutions are recorded in Tables $\mathbf{1}$ and $\mathbf{2}$. From these the superiority of Witte is very clear, especially with the standard Wijnberg strain of L. icterohaemorrhagiae. Within the range of concentrations used the effects of Witte peptone were wholly favourable, whereas the optimum in the middle of the range with this particular batch of Oxo peptone suggested the presence of both favouring and inhibitory materials. The L. canicola strain Aldgate was much less sensitive to inhibition by the Oxo peptone, grew more rapidly in all media, but like the Wijnberg strain came up first in the tube with the highest concentration of Witte peptone. This experiment differed from most of those made subsequently in that the medium was made up with a human serum which had been found suitable for culture of leptospira.

Other peptones. In a preliminary experiment in which the methods of preparation of peptone and media were similar to those just described the peptones investigated were those of Armour, Evans, Oxo, Parke Davis, Witte, 
Allen \& Hanbury's Eupeptone No. 2 and the Difco products, Bacto-, Neo- and Proteose-peptones. Good results were obtained with the peptones of Evans and of Parke Davis; fairly good with Difco-proteose and Oxo peptones; poor with Armour and Witte peptones. Eupeptone and the Difco Neo- and Bactopeptones failed to promote growth. A peculiar observation, however, was that on retesting these solutions after they had stood at room temperature for 14 days several of these results were reversed. These observations were also peculiar in

Table 1. Growth of Leptospira icterohaemorrhagiae, strain Wijnberg as affected by peptone concentration

The media were obtained by adding the appropriate volume of a $4 \%(w / v)$ solution of peptone (pH 7.8) which had been autoclaved for $20 \mathrm{~min}$. at $10 \mathrm{lb}$. $/ \mathrm{sq}$.in. to a filtrate of $10 \%$ $(\mathrm{v} / \mathrm{v})$ serum in diluted meat extract and incorporating clear water agar so as to give an agar concentration of about $1 \%$ in the completed medium.

\begin{tabular}{|c|c|c|c|c|c|c|c|}
\hline \multirow{4}{*}{$\begin{array}{c}\text { Peptone } \\
\text { Witte }\end{array}$} & \multicolumn{7}{|c|}{ Period of growth (days) } \\
\hline & \multirow{2}{*}{$\begin{array}{c}\text { Conen. } \\
(\%)\end{array}$} & 1-3 & 5 & 7 & 9 & 12 & 21 \\
\hline & & \multicolumn{6}{|c|}{ Degree of growth $(\mathrm{mm})}$. \\
\hline & & - & - 8 & - 10 & - 10 & - 10 & \\
\hline & 0.75 & - & - & - 9 & - 9 & - 10 & 12 \\
\hline & $0 \cdot 375$ & - & - & - 11 & - 11 & - 12 & \\
\hline & 0.19 & - & - & - 12 & - 12 & - 12 & \\
\hline & 0.075 & - & - & - 11 & - 11 & - 12 & $\checkmark$ \\
\hline & $0 \cdot 0375$ & - & - & O 14 & - 14 & 13 & - 12 \\
\hline Oxo & 1.5 & - & - & - & - & - & - \\
\hline & 0.75 & - & - & - & - & - & - \\
\hline & $\begin{array}{l}0 \cdot 375 \\
0 \cdot 19\end{array}$ & - & - & - & 二 & $\overline{\overline{10}}_{-11}$ & $\begin{array}{l}9 \\
-13\end{array}$ \\
\hline & 0.075 & - & - & 010 & - 10 & - 10-11 & -13 \\
\hline & 0.0375 & - & - & - & - & _- & 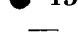 \\
\hline
\end{tabular}

$O=$ faint indication of disk; $O=$ frank disk; $-=$ no disk.

Figures indicate approximate distance below surface at which disk appears, e.g. 13 means three disks near together about $13 \mathrm{~mm}$. below surface.

that it was the only experiment of many in which Witte peptone proved less good than other peptones tested simultaneously. Following these results, Eupeptone, Evans, Oxo and Witte peptones were selected for further study.

Four methods of preparation of peptone solutions were compared: $(a)$ a $1 \%$ (w/v) solution was brought to $\mathrm{pH} \mathbf{7 \cdot 3}$ and autoclaved at $10 \mathrm{lb}$./sq.in.; (b) a $4 \%$ $(\mathrm{w} / \mathrm{v})$ solution was brought to $\mathrm{pH} 8.0$ and autoclaved at $10 \mathrm{lb} . / \mathrm{sq}$. in.; $(c)$ and $(d)$ as $(a)$ and $(b)$ but sterilized by filtration. The following results were obtained. 
Table 2. Growth of Leptospira canicola, strain Aldgate as affected by peptone concentration

\begin{tabular}{|c|c|c|c|c|c|c|c|}
\hline \multirow{4}{*}{$\begin{array}{c}\text { Peptone } \\
\text { Witte }\end{array}$} & \multirow{4}{*}{$\begin{array}{c}\text { Concn. } \\
(\%) \\
1.5\end{array}$} & \multicolumn{6}{|c|}{ Period of growth (days) } \\
\hline & & \multirow[t]{2}{*}{ 1-2 } & 3 & 5 & 7 & 14 & \multirow[t]{2}{*}{21} \\
\hline & & & \multicolumn{4}{|c|}{ Degree of growth (mm.) } & \\
\hline & & - & ○ 8 & - 8 & - 8 & 10 & 13 \\
\hline & 0.75 & - & - & 8 & - 8 & \}$_{10}$ & o\} \\
\hline & $0 \cdot 375$ & - & - & - 8 & - 8 & $\begin{array}{l}10 \\
-11\end{array}$ & 12 \\
\hline & $0 \cdot 19$ & - & - & - & - 9 & $\bullet$ & \\
\hline & 0.075 & - & - & - & - 9 & - 9 & \\
\hline & 0.0375 & - & - & 一 & - 8 & - 9 & \\
\hline Oxo & 1.5 & - & - & - & O 10 & 9 & 9 \\
\hline & $0 \cdot 75$ & - & - & 08 & 9 & - 8 & \\
\hline & $0 \cdot 375$ & - & - & - & ○ 10 & - 8 & \\
\hline & $0 \cdot 19$ & - & - & - & 010 & • 10 & 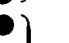 \\
\hline & 0.075 & - & - & - & - & - 8 & 1 \\
\hline & $0 \cdot 0375$ & - & - & - & - & 9 & 1 \\
\hline
\end{tabular}

Signs in this and in succeeding tables have the same significance as in Table 1.

(a) With a peptone concentration $0.5 \%(\mathrm{w} / \mathrm{v})$ in the completed medium all tubes containing peptone showed disk formation more rapidly than the culture in the control tube of basal medium when the $L$. canicola strain Aldgate was inoculated. With the strain Wijnberg, however, there was no evidence of growth in the tube containing Evans peptone, even up to 3 weeks incubation, although a well-defined disk had appeared in the control. In the media containing Witte peptone disks appeared 2-3 days before those in the media containing other peptones and at least a week before those in the control.

(b) Using the same final concentration of peptone as in (a) but a solution

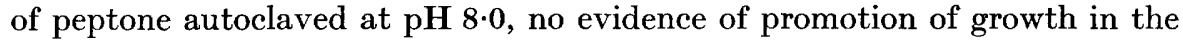
presence of peptone was obtained. All peptones except Witte appeared to be more or less inhibitory, and the result with Witte was no better than that obtained with the basal medium control.

(c) Using solutions as in $(a)$, but sterilized by filtration, all peptones were favourable with the strain Wijnberg, Witte being the best. With the strain 
Aldgate the Witte peptone again proved to be the best and superior to the control, whereas the three other peptones gave more retarded growth than in the control.

(d) Using solutions prepared as in (b), but in a final concentration of $0.12 \%$ and sterilized by filtration, no inhibitory results were obtained. Witte was still the best, and Evans and Eupeptone showed accelerated growth as compared with that in the control.

To sum up, these experiments suggest that filtered peptone solutions are better than autoclaved solutions and inhibitory effects are most likely to develop in slightly alkaline solutions of autoclaved peptone. In view of these findings an experiment on the effect of sterilizing peptone solutions by heat at different $\mathrm{pH}$ values was made.

\section{The $\mathrm{pH}$ values of cultures of leptospira and their correlation with profusion of growth}

Basal media of $\mathrm{pH}$ values as low as $6 \cdot 6-7 \cdot 2$ have been recommended for the growth of leptospira and this has left the impression that these microorganisms grow best at $\mathrm{pH}$ values slightly lower than those most suitable to the majority of pathogenic bacteria. On account of the importance of this point, and its significance in our experimental work, we examined it afresh, measuring $\mathrm{pH}$ values with a glass electrode and a Cambridge $\mathrm{pH}$ meter. The only account of observations on the electrometric measurements of $\mathrm{pH}$ values of media suitable for leptospiral culture of which we are aware is that of Walch-Sorgdrager et al. (1938). They concluded that it was possible to get growth in first subcultures in media ranging in $\mathrm{pH}$ values from 5.8 to 8.5 , but for repeated subculture $\mathrm{pH} \mathbf{7 \cdot 5}$ appeared to be the optimum.

Results. Parallel cultures of leptospira were made in a series of fluid media at graduated $\mathrm{pH}$ values and in a similar series solidified by agar buffered at $\mathrm{pH}$ 7.3. The liquid cultures were observed daily with the microscope (darkground illumination) for number and motility of leptospira and the solid cultures for the development of Dinger disks. The results are recorded in Tables 3 and 4. The enumeration of leptospira in liquid media suggested that initiation of growth was most rapid at $\mathrm{pH} 7.5$ but that initial $\mathrm{pH}$ values of 7.9 and $\mathbf{8 . 2}$ were at least as satisfactory for the ultimate development of wellgrown cultures. Values below $\mathrm{pH} \mathbf{7 \cdot 2}$ or above $\mathrm{pH} \mathbf{8 \cdot 2}$ delayed initiation of growth and full development of cultures. There was no evidence that the growth of the leptospira influenced the reaction of cultures, but in the liquid there was a marked tendency for the more alkaline media spontaneously to become gradually more acid. Within a week they all fell within the range $\mathrm{pH} \mathrm{7.5-7.8}$ in this experiment, although in another and similar one the acid drift was less marked and free growth appeared to have developed even at $\mathrm{pH} \mathrm{8.0.} \mathrm{The} \mathrm{general} \mathrm{indication} \mathrm{is} \mathrm{of} \mathrm{narrow} \mathrm{range} \mathrm{of} \mathrm{suitable} \mathrm{pH}$ values,

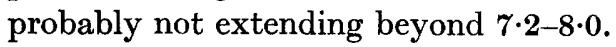

Determinations of $\mathrm{pH}$ values in solid media with glass electrodes presented difficulties. The procedure we adopted was to add $25 \%(\mathrm{v} / \mathrm{v})$ of $4 \%(\mathrm{w} / \mathrm{v})$ water agar buffered at $\mathrm{pH} \mathbf{7 \cdot 3}$ with $0.01 \mathrm{M}$-phosphate to a series of samples of 
liquid media adjusted to the desired $\mathrm{pH}$ values. Some of these were put up in duplicate, and these were used to determine the shift of $\mathrm{pH}$ consequent on the incorporation of the agar. Samples of liquid media containing Witte peptone and Eupeptone respectively were adjusted to $\mathrm{pH} 8.3$ by means of the glass electrode, and after incorporation of the agar were poured into the electrode chamber and allowed to set over the glass bulb. A reading was taken as soon as the solidified medium had reached room temperature; duplicate measurements showed $\mathrm{pH}$ of $7 \cdot 7$. It appeared that $\mathrm{pH}$ values of the liquid medium which were one $\mathrm{pH}$ unit or more alkaline to the $\mathrm{pH}$ value of the buffered agar

\section{Table 3. Effect of $\mathrm{pH}$ on development of leptospira in a favourable fluid} medium and its variation with growth of the leptospira

\begin{tabular}{|c|c|c|c|c|c|c|c|}
\hline \multirow{2}{*}{$\begin{array}{l}\text { Initial pH } \\
\text { of medium }\end{array}$} & \multicolumn{6}{|c|}{ Number of leptospira per field (dark background) on successive days } & \multirow{2}{*}{$\begin{array}{l}\text { Observation of } \\
\text { pH during } \\
\text { culture }\end{array}$} \\
\hline & 2nd & 3rd & 4th & 6th & 8th & 26th & \\
\hline $7 \cdot 2$ & 1, active & 5 , active & 15 , active & $\begin{array}{r}30-50 \\
\text { active }\end{array}$ & $\begin{array}{l}\text { 30, fairly } \\
\text { active }\end{array}$ & $\begin{array}{l}20-30, \text { long } \\
\text { and sluggish }\end{array}$ & \\
\hline $7 \cdot 5$ & 2, active & 30 , active & $>50$, active & $\begin{array}{l}50-70, \\
\text { active }\end{array}$ & $\begin{array}{c}50-100 \\
\text { active }\end{array}$ & $\begin{array}{l}\text { 50-60, long } \\
\text { mod. active }\end{array}$ & $\begin{array}{l}\text { 5th day : } \\
7 \cdot 56(7 \cdot 64)^{*}\end{array}$ \\
\hline $7 \cdot 94$ & 2, active & 10, active & 15, active & $\begin{array}{l}\text { 100, very } \\
\text { active }\end{array}$ & $\begin{array}{l}>100 \\
\text { active }\end{array}$ & $\begin{array}{l}>100, \text { mostly } \\
\text { very active }\end{array}$ & $7 \cdot 8(7 \cdot 84)^{*}$ \\
\hline $8 \cdot 2$ & 4, active & 7 , active & 15 , active & $50-60$ & $\begin{array}{l}>100 \\
\text { active }\end{array}$ & $\begin{array}{l}\text { 50-60, rather } \\
\text { sluggish }\end{array}$ & $\begin{array}{l}\text { 8th day: } \\
7 \cdot 5(7 \cdot 5)^{*}\end{array}$ \\
\hline $8 \cdot 6$ & 4 , active & $\begin{array}{l}\text { 5, some } \\
\text { sluggish }\end{array}$ & 30, active & 100 & 25, active & $\begin{array}{l}\text { 10-20, rather } \\
\text { sluggish }\end{array}$ & $7 \cdot 7(7 \cdot 7)^{*}$ \\
\hline $8 \cdot 8$ & 2, sluggish & $\begin{array}{l}\text { 4, some } \\
\text { sluggish }\end{array}$ & 5, sluggish & $20-40$ & 5-20, active & $\begin{array}{l}\text { 70-100, mostly } \\
\text { sluggish }\end{array}$ & \\
\hline
\end{tabular}

Strain: L. Wijnberg.

Medium: as for Table 4 without agar.

* Figures in brackets indicate the drift of $\mathrm{pH}$ level in uninoculated control samples of media of the same initial $\mathrm{pH}$.

( $\mathrm{pH} 7.3$ ) changed to a $\mathrm{pH}$ about 0.5 unit towards the acid side when the agar was added in the quantity used in our experiments. In Table 4 are recorded both the reaction of the liquid medium to which the water agar was added and the probable reaction of the completed solid medium, computed on this basis. The observations on growth in solid media at different $\mathrm{pH}$ values recorded in Table 4 indicate $\mathrm{pH} \mathbf{7 \cdot 4}$ as an optimum with a marked check on growth below $\mathbf{7 \cdot 2}$ and above $\mathbf{8} \cdot \mathbf{0}$. Other similar experiments were carried out and included some with media prepared with Eupeptone and inoculated with $L$. canicola Aldgate. The results were all very similar, but some of them indicated a rather greater tolerance of alkaline reactions than shown in Table 4. In all, the indication seems to be that there is a rather narrow $\mathrm{pH}$ range for optimal growth, a rather marked sensitivity to acid reactions and more tolerance for media of which the initial reaction was too alkaline rather than too acid.

\section{Effect on the nutritive quality of peptone of the $\mathrm{pH}$ value at the time of autoclaving}

The peptone solutions $(2 \%, \mathrm{w} / \mathrm{v})$ were divided into seven portions and by addition of acid or alkali these were adjusted to a range of $\mathrm{pH}$ values between 
Table 4. Development of Dinger's disks in cultures of varying initial $\mathrm{pH}$ at intervals of days

\begin{tabular}{|c|c|c|c|c|c|c|c|c|c|}
\hline \multicolumn{10}{|c|}{ 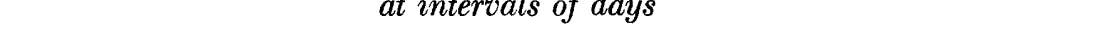 } \\
\hline $\begin{array}{l}\mathrm{pH} \text { of } \\
\text { fluid }\end{array}$ & $\begin{array}{c}\text { Computed } \mathrm{pH} \\
\text { of solid medium }\end{array}$ & $\begin{array}{l}\text { 4th } \\
\text { day }\end{array}$ & $\begin{array}{l}\text { 5th } \\
\text { day }\end{array}$ & $\begin{array}{l}\text { 6th } \\
\text { day }\end{array}$ & $\begin{array}{l}\text { 7th } \\
\text { day }\end{array}$ & $\begin{array}{l}\text { 8th } \\
\text { day }\end{array}$ & $\begin{array}{l}\text { 9th } \\
\text { day }\end{array}$ & $\begin{array}{l}\text { 16th } \\
\text { day }\end{array}$ & $\begin{array}{l}23 r d \\
\text { day }\end{array}$ \\
\hline $7 \cdot 2$ & $7 \cdot 2$ & - & - & - & - & 0 & $\bullet$ & • & $\bullet$ \\
\hline 7.5 & $7 \cdot 3$ & - & - & $\bullet$ & • & : & & & 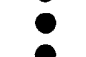 \\
\hline 7.94 & 7.5 & - & • & • & $\stackrel{0}{0}$ & • & : & & \\
\hline 8.2 & $7 \cdot 7$ & - & - & 0 & - & $\bullet$ & 0 & 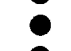 & • \\
\hline $8 \cdot 6$ & 8.0 & - & - & - & - & • & - & 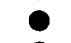 & 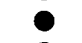 \\
\hline 8.8 & $\begin{array}{l}8 \cdot 2 \\
8 \cdot 6^{*}\end{array}$ & - & - & 二 & - & - & $\underline{-}$ & $\underline{\bullet}$ & - \\
\hline
\end{tabular}

Strain: L. Wijnberg.

Medium: pooled rabbit serum

Witte peptone

$10 \%$ meat extract in aq. dist.

$\left.\begin{array}{r}10 \%(v / v) \\ 0 \cdot 1 \%(w / v) \\ 90 \%(v / v)\end{array}\right\} 3$ parts to 1 part $4 \%(w / v)$ of water agar.

* Actual $\mathrm{pH}$ determined after addition of alkali.

4 and 8.9 before autoclaving at $10 \mathrm{lb}$. $/ \mathrm{sq}$.in. for $20 \mathrm{~min}$. The reaction of each was then adjusted and after the addition of the other ingredients of the liquid media all were found to be within the $\mathrm{pH}$ range $7 \cdot \mathbf{3}-7 \cdot 5$, with one exception. This was the sample of Witte peptone which had been autoclaved at $\mathrm{pH} 4$ and had only been brought back to $\mathrm{pH} \mathrm{6.9}$. It was assumed, in view of the results above, that the further addition of agar would leave all media so near the optimal reaction for growth that the conclusions with regard to the effect of autoclaving peptone at different $\mathrm{pH}$ values were likely to be valid. The concentration of peptone in the completed media was $0.5 \%(\mathrm{w} / \mathrm{v})$. The media were inoculated as before with the strains Wijnberg and Aldgate. With Eupeptone the $\mathrm{pH}$ range actually obtained was from $4 \cdot 34$ to $8 \cdot 9$. There was complete inhibition of both strains by the peptone solution autoclaved at $\mathrm{pH} 8 \cdot 9$. All samples autoclaved at $\mathrm{pH}$ values between $7 \cdot 9$ and $4 \cdot 34$ showed welldeveloped disks after 3, 4 or 5 days of incubation. With Witte peptone the range of $\mathrm{pH}$ values obtained was from 4 to 8.74 at time of autoclaving. No inhibition of growth was observed. There was slight retardation of growth in a few cultures, and slight acceleration in some others.

\section{Effect of different concentrations of meat extract}

The leptospira tolerated considerably higher concentrations of meat extract than those commonly used in media such as Fletcher's, but they did not tolerate those used in everyday bacteriological work. This inhibition at high concentrations of meat extract was found to be diminished in the presence of Witte peptone but increased with the Oxo product.

Tryptic digest broth. Hartley's tryptic digest broth, modified according to Mackie \& McCartney (1950), in concentrations of $8-60 \%(v / v)$ was solidified 
with water agar and compared with the meat extract Witte peptone agar of varying peptone content from $0 \cdot 16$ to $0 \cdot 4 \%(\mathrm{w} / \mathrm{v})$. Both series of media included the usual amount of rabbit serum. In two experiments the media with Hartley broth proved superior; although this cannot be claimed to be significant without further trials we were impressed with the fact that this was the only medium amongst those tested which showed development of a second disk as early as the third day.

\section{DISCUSSION}

The results recorded show that most peptones in suitable concentrations will increase the speed of the growth of leptospira in a basal medium of $10 \%(\mathrm{v} / \mathrm{v})$ rabbit serum in diluted extract of meat, although the best samples of the basal medium grow the leptospira well without any addition of peptone. Inhibitory effects, however, occur with many peptones, especially when they are at concentrations above $0 \cdot 1 \%$. The cause of such inhibitory effects is not clear, but they are more liable to occur when the peptone is autoclaved at $\mathrm{pH} \mathbf{7 \cdot 8}$ or more. They are rarely met, however, with Witte peptone, and in many experiments better growth was obtained with concentrations of this product much higher than those generally recommended. Some bizarre results were obtained when different peptones were compared immediately after autoclaving and again after standing in solution for a fortnight at room temperature exposed to diffuse daylight. Some were favourable for growth at the outset but inhibitory after standing, while the reverse effect was observed with others.

Czekalowski et al. (1953) drew attention to the fact that leptospira are devoid of catalase. On this account they may be particularly sensitive to the traces of $\mathrm{H}_{2} \mathrm{O}_{2}$ which tend to accumulate in solutions containing organic matter when allowed to stand exposed to light (see Bedford, 1927). This may explain the advantage often claimed from adding haemoglobin to media for growing leptospira. When the haemoglobin is added as laked blood (the usual practice), it is of course a material rich in catalase. Wiesmann (1952) stated that he found no advantage in adding haemoglobin to his media, but since he insisted that the rabbit serum used must be fresh, this may only mean that there is no advantage in adding catalase to a medium which already contains it. Our observations are in line with those of Walch-Sorgdrager et al. (1938) in finding $\mathrm{pH} 7 \cdot 5-7 \cdot 6$ as the optimum for leptospiral growth, which might be expected with a pathogenic organism which invades animal blood and tissues. Our observations suggest, however, that sensitivity to variations from this $\mathrm{pH}$ value are more marked on the acid than on the alkaline side and that a basal medium of $\mathrm{pH} \mathbf{7 \cdot 6 - 7 \cdot 8}$ is probably safer than one of $6 \cdot 8-7 \cdot 2$, as often recommended. It is interesting in this connexion that Thiry \& Meirhaeghe (1932), in a study of the optimum $\mathrm{pH}$ for growth of leptospira in Vervoort medium no. 2 , found this to range from $\mathrm{pH} 7 \cdot 8$ to $9 \cdot 0$ for six strains of $L$. icterohaemorrhagiae and from $\mathrm{pH} 6 \cdot 6$ to $7 \cdot 2$ for two leptospira strains from water. Three of their L. icterohaemorrhagiae strains failed at $\mathrm{pH} 7 \cdot 0$. They do not state, however, how their $\mathrm{pH}$ values were determined. 
We are much indebted to Mr G. Eaves for help in translating Dinger's paper from the Dutch, to Mr T. Varley for much painstaking work in the preparation of media and to the Medical Research Council for a grant.

\section{REFERENCES}

BEDFord, T. H. B. (1927). The nature of the action of ultraviolet light on microorganisms. Brit. J. exp. Path. 8, 437.

Czekalowski, J. W., McLeod, J. W. \& Rodican, J. (1953). The growth and respiration of leptospira on solid or semi-solid media with special reference to Dinger's phenomenon. Brit. J. exp. Path. 34, 588.

Davidson, L. S. P., Campbelt, R. M., Rae, H. J. \& Smith, J. (1934). Weil's disease (Leptospirosis). A clinical and bacteriological study of 19 cases occurring chiefly amongst fish workers. Brit. med. J. ii, 1137.

Dinger, J. E. (1932). Duurzaamid der Smetkracht van Leptospirenkweeken. Geneesk. Tijdschr. Ned.-Ind. 72, 1511.

Fletcher, W. (1928). Recent work on leptospirosis. Trans. R. Soc. trop. Med. Hyg. 21, 265.

Konthof, G. (1928). Proeven met Leptospira icterohaemorrhagiae. Versl. Volksgezondh., Amst., p. 1272.

Lawrence, J. J. (1951). The growth of leptospira in semi-solid media. Aust. J. exp. Biol. med. Sci. 29, 195.

Mackie, T. J. \& McCartney, J. E. (1950). Handbook of Practical Bacteriology, 8th ed., p. 146. Edinburgh: E. and S. Livingstone and Sons Ltd.

Noguchi, H. (1918). Further study on the cultural conditions of Leptospira (Spirochaeta) icterohaemorrhagiae. J. exp. Med. 27, 593.

Stuart, R. D. (1943). A study of leptospirosis in the south-zest of Scotland. Thesis. University of Aberdeen.

Stuart, R. D. (1946). The preparation and use of a simple culture medium for Leptospirae. J. Path. Bact. 58, 343.

Thiel, P. H. van (1948). The Leptospiroses. Leiden: Universitaire Pers.

Thiry, U. \& Meirhaeghe, A. (1932). Recherches complémentaires sur les Leptospires aquicoles et les Leptospires ictérohémorrhagiques. Rev. belge. Sci. med.4, 441.

Vervoort, H. (1923). Spirochaeten bij acute koortsige ziekten van onbekenden oorsprong in de tropen. Geneesk. Tijdschr. Ned.-Ind. 63, 800.

Walch-Sorgdrager, B., Schüffner, W. \& Bohlander, H. (1938). Der Einfluss des Säuregrades auf die Seroreaktion und das Wachstum der Leptospiren. Z. ImmunForsch. 92, 35.

Wiesmann, E. (1952). Leptospirosen. (Gsell, O. mit Anhang von E. Wiesmann.) Bern: Hans Huber, Medizinischer Verlag.

Zuelzer, M. (1936). Zur Biologie und Epidemiologie der Weilschen Krankheit. Zbl. Bakt. (1 Abt. Orig.), 137, 189. 